\title{
6. The Pattern of Forced Exits from the Ministry
}

\author{
Keith Dowding, Chris Lewis and Adam Packer
}

\section{Introduction}

Ministers leave office for all sorts of reasons. The most dramatic exits are those that are forced. We define a forced exit as one that happens at a time not of the prime minister's choosing. The prime minister might demand a resignation because of some scandal, but she did not want that scandal to emerge and compel her to ask for the minister's resignation. A forced resignation can also occur when a minister resigns because they disagree with government policy, because of a personality clash or simply as part of a strategic ploy to enhance his or her own leadership ambitions. We do not include cases where a minister is asked to leave at a time of the prime minister's choosing - for example, John Howard's penchant for asking ministers to step down during the Christmas break (see below and Chapter 2). Forced exits therefore include cases of what Woodhouse (1994, 33-8) calls 'sacrificial responsibility' - part of individual ministerial responsibility, but also where ministers depart of their own volition because they cannot abide by collective cabinet responsibility.

In this chapter we examine the pattern of individual resignations in the Australian Commonwealth Government since 1949, from the incoming Menzies Government to the end of Kevin Rudd in 2010. We have collected data on all resignations and non-resignations over the period (see below and Appendix 6.1 for details). Our analysis is largely descriptive, to examine the lie of the land, so to speak. But one of our aims is to see whether the pattern of forced exits has changed over time.

Many commentators believe that Australian prime ministers are too reluctant to sacrifice ministers following scandal (Mulgan 2002). John Howard was particularly criticised for his reluctance to dispose of ministers in his later years in office. In a letter to the Herald-Sun (12 November 2007), two former prime ministers, Gough Whitlam and Malcolm Fraser, wrote:

In the last two decades the constitutional principle that ministers should be held accountable for the failings of their policies or administration has been seriously undermined.

No matter how grave their failings may be, ministers no longer resign. 
Academic commentators are more circumspect. Page (1990) and Thompson and Tillotsen (1999) have documented when Australian federal ministers have resigned, but they also note that it has never really been the Australian tradition for ministers to resign for departmental or policy failings (nor indeed has it been in other Westminster systems: see, for example, Dowding and Kang 1998; McLeay 1995, Ch. 5; Woodhouse 1994). Indeed, as Richard Mulgan points out in Chapter 9, the textbook account of ministerial responsibility means that all prime ministers are bound to fail it. Nevertheless, it is worthwhile examining the pattern of forced exit over time to see whether we can discern changes in how prime ministers respond to criticism of their ministers. In order to do that we need to look not only at cases where ministers do resign, but also those where they do not.

\section{Calls to Resign}

Sacrificial responsibility is the ultimate public face of ministerial accountability and, as the letter from Whitlam and Fraser suggests, is often thought to be the mark of ministerial responsibility. One way of ensuring that a prime minister's government looks unaccountable is, however, to make lots of calls for resignation. It is clear from our data that many calls are trivial. Rather than use our own subjective judgment about what is trivial and what important, we chose to use our source as a guide. From our original data-which collected all calls for resignation from parliamentarians, elite figures, organisations such as trade unions or from newspaper columnists - we culled those that were not repeated in the media over two or more days. So we only report here cases where the media reported the call and then discussed the issue over several days. We do not claim that all of the cases in the data reported here are 'objectively serious' but we have excluded many cases that are clearly trivial. ${ }^{1}$

Figure 6.1 demonstrates that the number of resignation calls has increased over time (and that increase is even larger if the trivial items are included). Later we will categorise these calls and see where they have been increasing. Figure 6.1 shows a sharp rise in the early 1970s, corresponding with Whitlam's administration, and a further rise under Fraser. We also see large rises under Howard's administration. The figure shows the actual number of calls annually and a smoothed trend line. The trend line is important as it demonstrates how parliamentarians, elites and the media are more likely to call for resignations over time. The trend line falls towards the end but it is too soon to tell if this is a temporary or more permanent phenomenon.

1 For example, in the data we report here we have 35 cases of non-resignation distilled from 94 in our full set; we use 12 cases of departmental error of 25 in our full set; 13 financial scandals out of 42, and so on. 


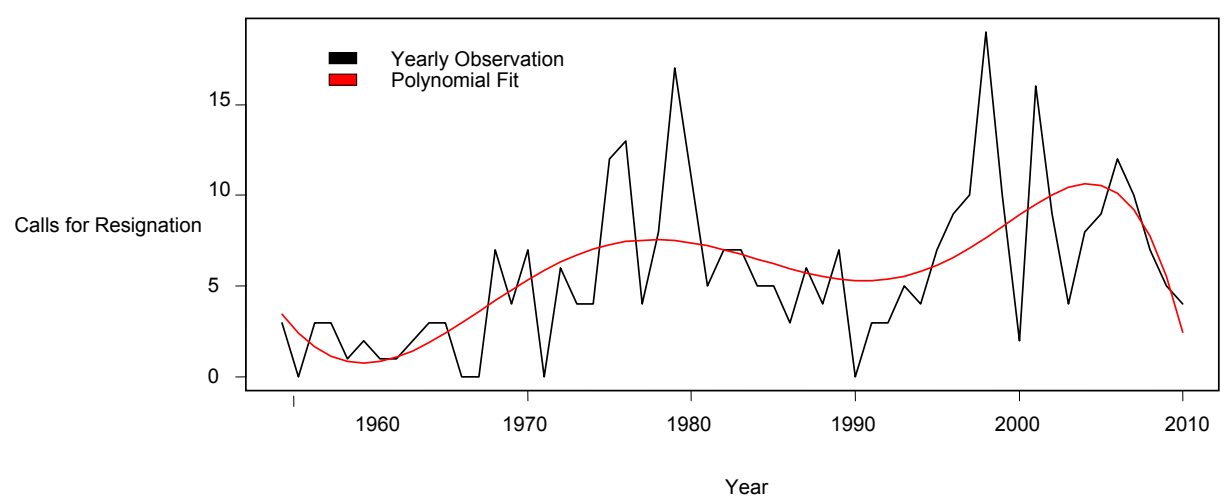

Figure 6.1 Calls for Resignation Over Time

\section{Proximate Causes of Forced Exit}

In this chapter we are examining the proximate causes of forced exit - that is, the specific events that led to a minister resigning at the time he did. Proximate causes are contrasted with ultimate causes, which would include factors shown to have been important in ministerial turnover, such as the age of the minister, previous scandals in cabinet, the relative popularity of the government in the polls, and so on (Berlinski et al. 2007, 2010, 2012; Dewan and Dowding 2005). Our aim is to describe the proximate causes of forced exit, examining trends over time, not to explain the ultimate causes and underlying conditions that lead to forced exit.

It would be a mistake to examine only ministerial resignations when attempting to identify the proximate cause of forced exits. Selecting the dependent variable might lead one to conclude that certain proximate factors lead to resignation when in fact a very small percentage of such cases leads to resignation. To overcome that fact we have coded all cases from 1947 to 2010 where there has been a call for a minister to resign. Such 'resignation issues' are composed of resignations and 'non-resignations' where a call has come but the minister has remained in place. The calls have been recorded from those reported in the newspapers (The Age, The Australian and the Sydney Morning Herald), and all cases have been coded according to a set of categories (see Appendix 6.1 for details of the coding methods).

In this chapter we consider a minister to be anyone with ministerial responsibility reporting to either house, thus including people in both inner and outer ministries. The number of ministers has changed over time, with 19 
under Menzies' first government, while Howard had 18 in his last cabinet plus 14 in the outer ministry. The number of ministers may vary over any given administration, but not by much.

In what circumstances are ministers forced out? We do not include the 30 departing ministers who have been coded as retirement/outside appointment/ shuffled out. We note here that 10 of these cases occurred under Robert Menzies and eight under Howard; both had long administrations so faced ageing cabinets that needed reinvigorating now and then. One example is Walter Cooper who resigned in December 1960 as Minister for Repatriation; he was then seventy-two (though he remained in Parliament for another eight years). Under Menzies, nine ministers resigned or announced their intention to resign during a government term to take up other positions, including five who left to take up diplomatic posts; most were in their sixties or seventies. Towards the end of his time in office, Howard would take the Christmas break to consider his cabinet and have a reshuffle in late January. No other prime minister moved on ministers in quite such a measured, post-Christmas manner. Note that one reason ministers might be moved on is because they faced earlier resignations calls; nevertheless, they did not go at the time of those calls, but later, at the prime minister's own choosing. ${ }^{2}$

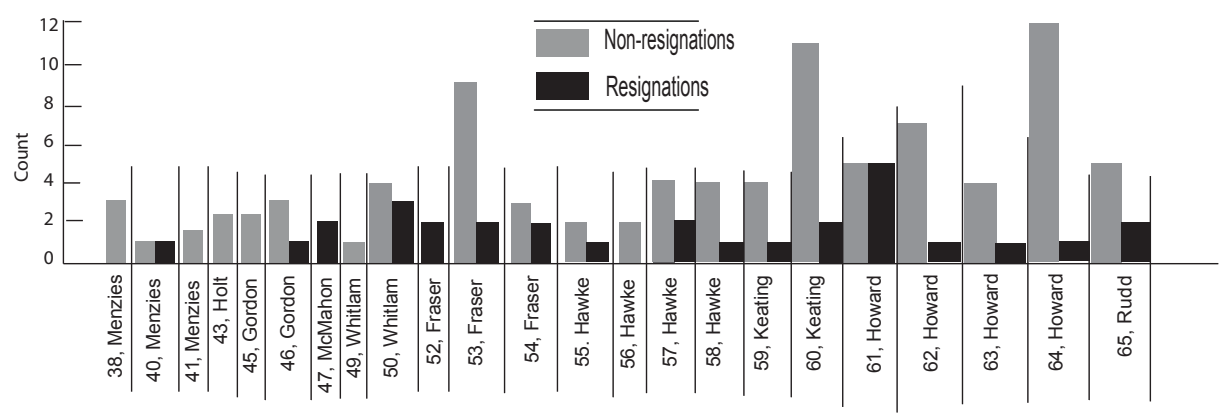

Figure 6.2 Resignations and Non-Resignations by Government, 1949-2010

Figure 6.2 compares the number of resignations with non-resignations by government; we have removed those short-term governments with no resignations or non-resignations. There appears to be no particular pattern to the resignations: some parliaments have few, others 10 or so. But it is clear that the number of non-resignations has increased dramatically over time. There are some peaks in the mid-1970s - notably the fiftieth government (Whitlam's third administration) and the fifty-third (the third Fraser administration)-but the largest rise comes with the sixtieth government (Keating's second administration), with further rises under Howard. This pattern of increasing numbers of calls

2 Such earlier non-resignations feature in the ultimate explanation of ministerial turnover, but not in consideration of proximate cause. 
for resignations matches trajectories in other countries (Dowding and Dumont 2009a; Dowding and Kang 1998; Fischer et al. 2006) and is certainly due in part to increased media attention to ministerial behaviour - though we note the few calls in Rudd's two and a half years. Of course, as we mentioned in the introduction, Howard was criticised for allowing standards of sacrificial accountability to slip: ministers did not resign following problems within their departments, with decisions they made or general behaviour.

There are many reasons for the increase in calls. There are a greater number of controversial issues as the policy agenda has grown, particularly since the time of Gough Whitlam (Dowding et al. 2010). Issues such as share-ownership and travel expenses have become controversial and worthy of press comment whereas in the past they were ignored (Dowding and Lewis 2012). Many calls in recent years are simply appended to criticisms of ministers' policies. Furthermore, the press and opposition have become more vitriolic in their criticism.

Figure 6.3 breaks the resignations and non-resignations down by prime minister, but since prime ministers serve for different periods we weighed the number of calls for resignation by the number of days in office. Here we see the charge against Howard loses some force. Whitlam had the same number of calls per day (though a slightly higher number of resignations per day in office) with Fraser not so far behind.

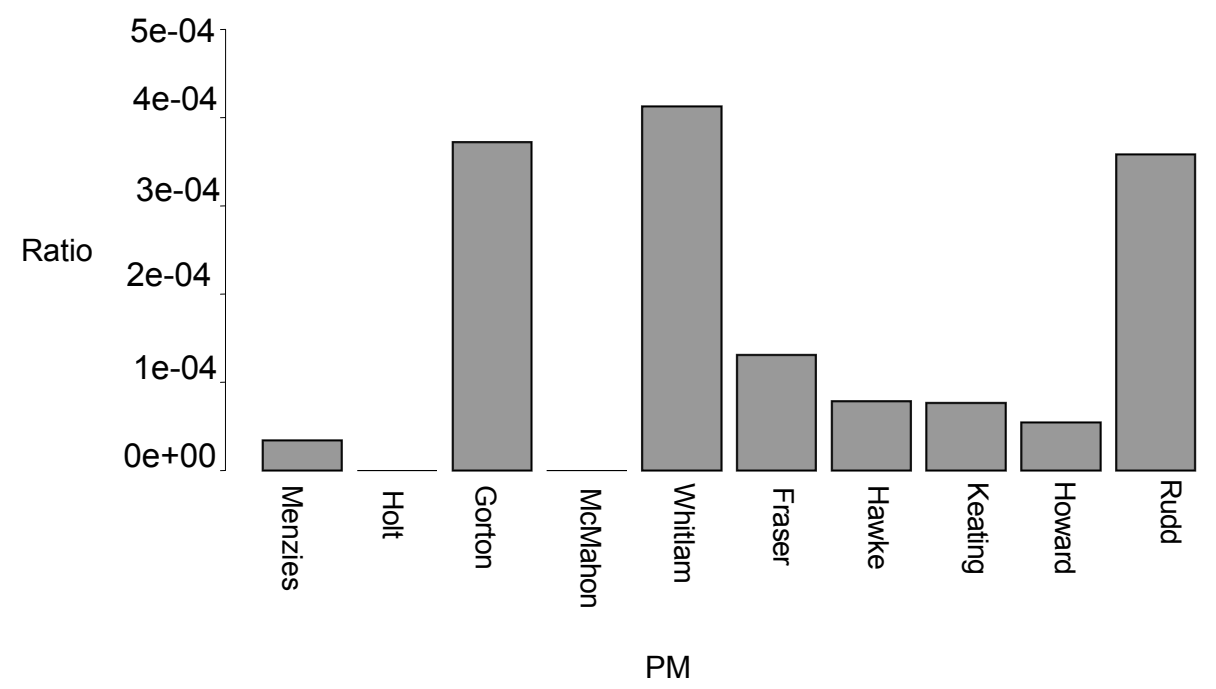

Figure 6.3 Proportion of Resignations to Calls for Resignation by Prime Minister, Weighted by Days in Office, 1949-2010 
One way of considering the issue would be to look at the proportion of resignations relative to the number of calls for resignation. This has been called the 'honour ratio' (Dowding and Kang 1998) though the title is perhaps misleading given that even in our restricted set some calls for resignation might be considered mischievous.
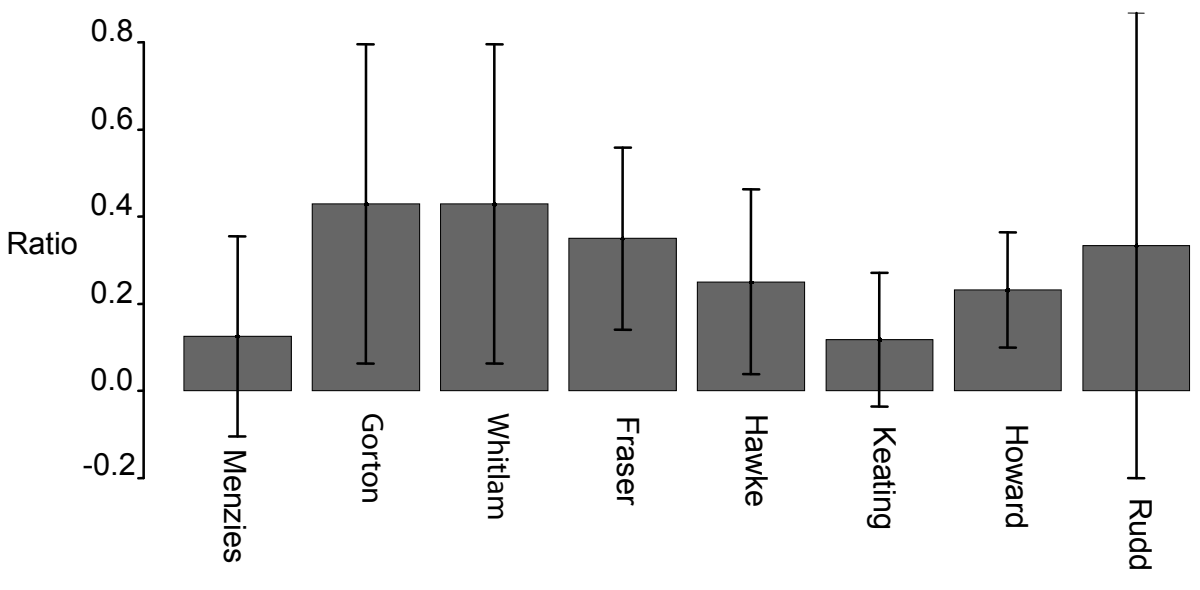

PM

Figure 6.4 Proportion of Resignations to Calls for Resignation by Prime Minister, 1949-2010

Figure 6.4 shows the proportion by prime minister. We see here that in fact Howard has fewer calls per resignation than Keating or Menzies; however, given the small numbers and the increasing calls over time we cannot make much of this. We also put 95 per cent confidence intervals on the figure. The 95 per cent confidence intervals are estimated by the binomial distribution, which approximates a normal distribution for $n$ larger than about 25-30, and so are not very accurate except for the Fraser, Hawke, Keating and Howard entries. ${ }^{3}$ This shows that even with the caveats already made, Keating's upper bound is within the proportions for Hawke and Howard, showing a slightly more than 95 per cent probability that Keating's rate of turnover is within the average range for Hawke and Howard. This means we cannot assume from the figure (even ignoring the caveats above) that Keating's ministers were less accountable than Hawke's or Howard's.

3 For $n$ trials and $p$ probability of success, the confidence interval is given by $p+-1.96^{*}\left(p^{*}(1-p) / \mathrm{n}\right)$. 


\section{Reasons for Resigning}

What are the proximate reasons that force ministers to exit? We see in Figure 6.5 that by far the greatest number of resignation calls relate to personal error. Personal error includes all decisions made by a minister in his or her capacity as a minister. An example is Gerry Hand's non-resignation over misleading Parliament about funding for the National Aboriginal and Islander Health Organisation. Hand did in fact offer to resign but Hawke supported him and would not accept the resignation. The resignations in this category are: Reg Withers (Administrative Services), August 1978; Mick Young (Special Minister of State), July 1983; John Brown (Arts and Environment), December 1987; Ros Kelly (Environment, Sports and Territories), February 1994; Ian Campbell (Environment), March 2007. The McGregor Royal Commission on electoral redistribution in Queensland found Withers had acted improperly to get the name of an electorate changed, and Fraser dismissed him when he refused to resign. Young was asked to resign by Hawke following the former's admission that he had leaked to a lobbyist that the Government was about to expel a Soviet diplomat. Young was later reinstated after party pressure, despite a report tabled in Parliament that Justice Hope believed that his actions gave rise to a real danger of damaging national security. John Brown resigned in December 1987 for misleading Parliament over the 1988 Expo in Brisbane. Ros Kelly resigned in February 1994 after she admitted that she had approved a sports grant her department considered ineligible. Her problem was not simply the pork barrel, which has long been a practice of Australian politicians, but her failure to keep proper documentation, and her failure to answer questions in Parliament because she was 'rostered off' for that Question Time. Perhaps what eventually led her to resign was the charge that she had misled Parliament and the fact that the affair had rumbled on for most of February, with her resignation coming on the last day of that month. Ian Campbell resigned four days after reports that he had met with the controversial Brian Burke, a former Labor premier of Western Australia and then a lobbyist for WA business interests. With ministers in Western Australia banned from speaking to Burke by the Premier, Geoff Gallop (an edict rescinded by his successor, Alan Carpenter), and the Corruption and Crime Commission investigating Burke's affairs, the Howard Government was attempting at this time to embarrass Labor's new leader Kevin Rudd over his own meeting with Burke. When Treasurer, Peter Costello, asserted that 'anyone who deals with Burke is morally and politically compromised', Campbell resigned quickly to end any Liberal embarrassment. 


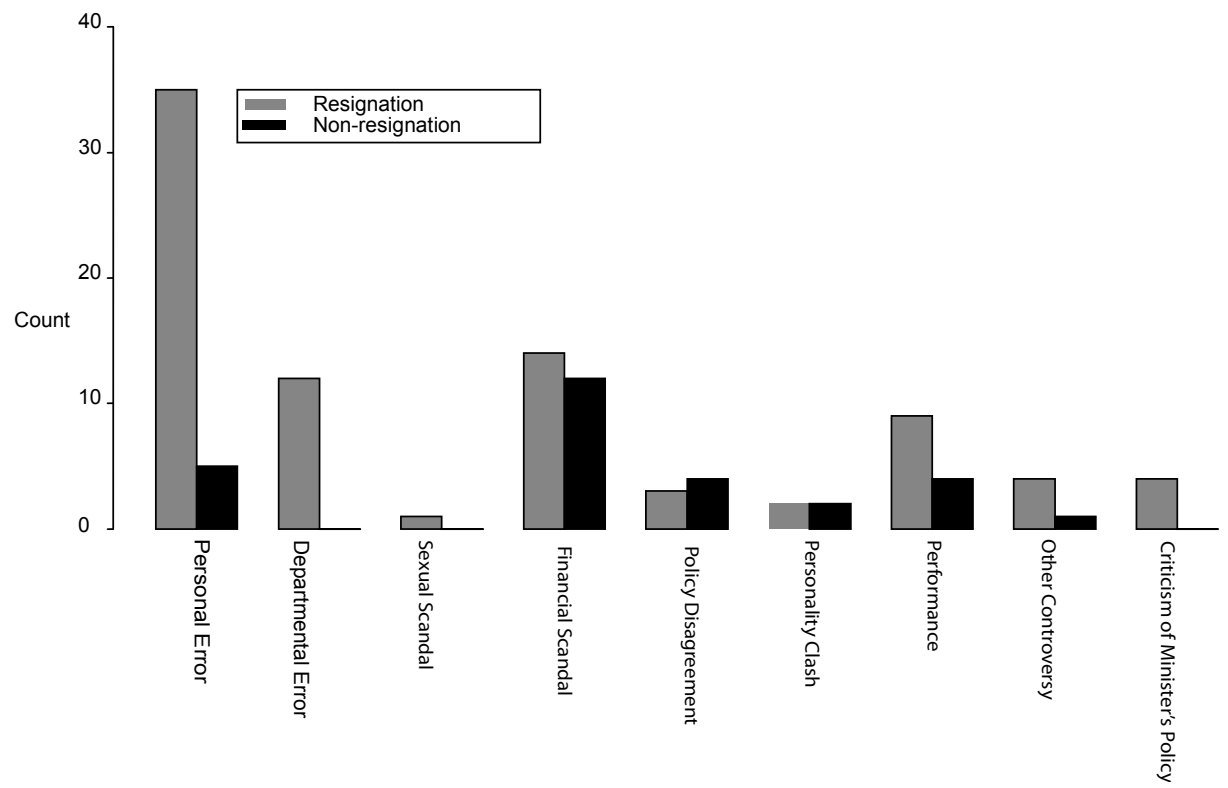

Figure 6.5 Reasons for Call to Resign by Event, 1956-2010

Non-resignations in Howard's government in this category include Alexander Downer (in April 2006) - Rudd suggested Downer had misled either Parliament or the Cole corruption inquiry into the Australian Wheat Board kickbacks scandal (McConnell et al. 2008, 208; Overington 2007; Volcker 2005); DeAnne Kelly in December 2004, despite Howard's admission she had broken the ministerial code of conduct in unlawfully approving grants to electorally sensitive areas unconnected with her portfolio; Robert Hill, who had failed to act on senior Australian military lawyers' reported concerns over the treatment of prisoners in Iraq; Bronwyn Bishop (March 2000), following reports she had misled Parliament the previous year when she had said spot checks on nursing homes would continue when in fact they had not started; there were additionally several calls for Howard to resign following claims he had misled Parliament over the children overboard affair (Keating 2003; Marr and Wilkinson 2003; Weller 2002) and, earlier, over meetings with businessman Dick Honan.

The next largest category of non-resignations is financial scandal though it has the highest number of resignations. This category has the highest proportion of resignations to resignation issues (resignations and non-resignations combined), demonstrating the seriousness with which financial scandals are treated, even when relatively trivial. The earliest resignation over financial matters occurs in July 1975. Whitlam forced Jim Cairns to resign after the minister first denied and then claimed to have no memory of authorising businessman George Harris to investigate the raising of overseas loans. It was part of the loans affair that was instrumental in the fall of Whitlam's government, and the day after Cairns 
resigned Queensland Premier, Joh Bjelke-Petersen, called on the Coalition to demand Whitlam's resignation. Rex Connor was also caught up in the loans affair, though he was actually dismissed on the basis that he had misled the Prime Minister over continued links with Tirath Khemlani after his authority to seek overseas loans had been withdrawn.

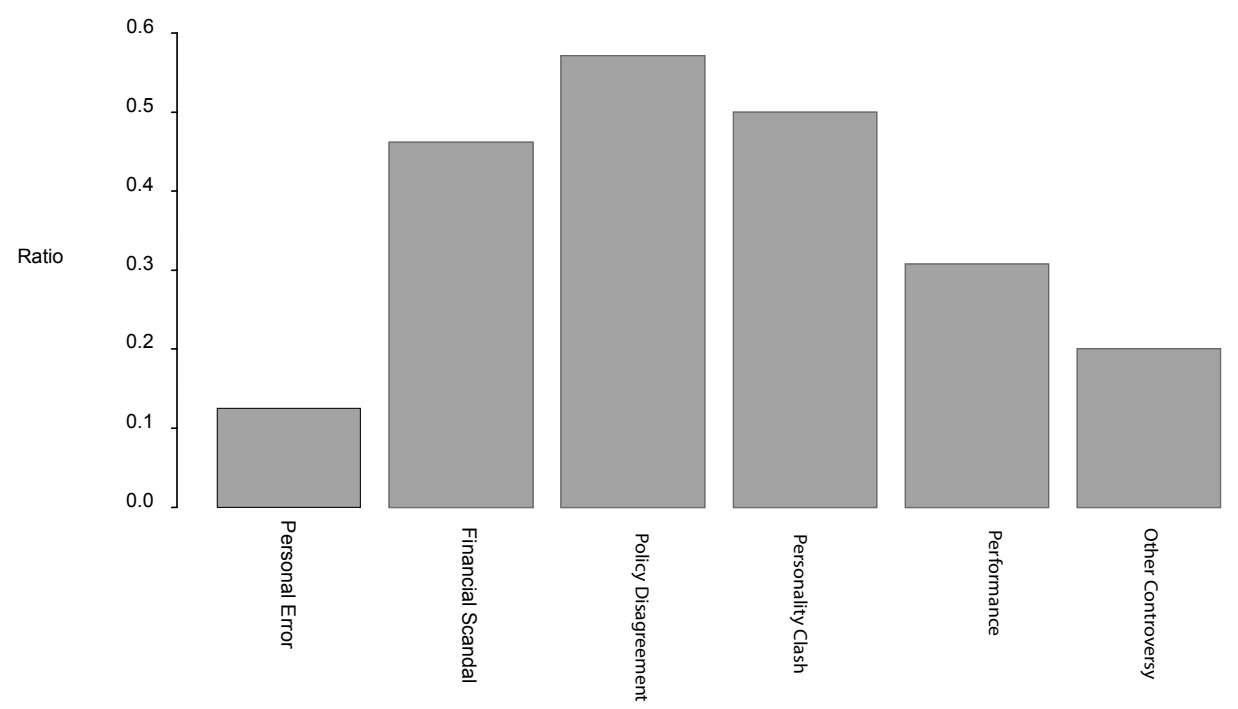

\section{Figure 6.6 Proportion of Resignations to Calls for Resignation by Reason}

Victor Garland resigned over the relatively trivial matter of an independent senate candidate giving \$500 in expenses at Garland's office. Garland was cleared of any wrongdoing six weeks after resigning. Phillip Lynch resigned, despite having the full confidence of Prime Minister Malcolm Fraser, because of allegations about his family's business interests. He was likewise vindicated, just a month after resigning.

Ian Sinclair finally went in September 1979 after the Finanne Report concluded he had not been honest in his business dealings or his explanation of arranging loans from a group of companies of which he was de facto managing director. He had survived three earlier calls to step down (May and October 1978, and June 1979) when his business dealings were under investigation. Michael MacKellar resigned as Health Minister and John Moore as Business and Consumer Affairs Minister responsible for customs in April 1982 after four days of criticisms following MacKellar's admission that six months earlier he had made a false customs declaration to avoid paying duty on an imported television. Fraser demanded both resignations though Moore argued he had done nothing wrong. Mick Young resigned in February 1988 following a police investigation into Labor's failure to disclose a \$10 000 election campaign donation. Prime Minister 
Hawke accepted the resignation reluctantly, saying that sections of the media had treated Young 'appallingly badly'. Graham Richardson resigned as Minister for Communications over his failure to register his interest that he was a director of a radio station and his failure to quit the directorship immediately he was appointed to the ministry. The issue broke on 30 April though Richardson did not resign until 19 May. A further factor was Richardson's denial (on 29 April) that he had knowledge of his cousin-in-law Greg Symons's business interests, ${ }^{4}$ confounded by the revelation on 8 May that he had written a letter of recommendation to the Government of the Marshall Islands to help Symons in his business there. Alan Griffiths resigned in January 1994 following allegations about the possible misuse of funds received for party political purposes to meet the debts of a shop of which he was a part-owner. Joel Fitzgibbon resigned in June 2009, as we shall discuss below.

Eight resignations due to financial scandal came under Howard, the first two (Jim Short and Brian Gibson) snared by Howard's new ministerial code (Howard 1996). Short owned extensive banking shares whilst being responsible for banking matters; Gibson owned bank shares, though he argued he was not responsible for banking policy. (John Moore faced calls for resignation over share-ownership at the same time, but managed to survive.) They began the series of forced exits in Howard's first administration. Santo Santoro went late in Howard's final administration for failing to register shares. Bob Woods resigned over parliamentary expenses; John Sharp and David Jull over false travel allowance claims, followed by Peter McGauran a few days later. Bruce Scott also faced calls for his resignation but weathered the storm. We include Mal Brough, though he was forced to stand down before he was sworn in as minister because of allegations of electoral rorting during a State election in Queensland. Howard relaxed his code following the rush of resignations in his first term, but they almost certainly gave a taste for blood to the Opposition and press.

We will not discuss all the calls for resignation that did not lead to exit, some for relatively trivial issues, but we note that Mick Young faced such a call in July 1984 for making a false customs declaration - a similar, though perhaps not as serious, case as that which led to two ministers resigning under Fraser. John Dawkins and John Button did not resign after claims of conflict of interests. Dawkins was Minister of Trade and admitted knowing his mother owned shares in a company, and Button held shares when Minister of Technology and Commerce. Chris Hurford survived, despite a story that he had promised scoops in return for a regular radio spot on an Adelaide commercial radio station, though there is some doubt about how serious this allegation really was. John Brown did not resign after it emerged that his wife had cashed in a first-class

4 As this is a separate issue that went away, but came back and was relevant to his final resignation, we have coded the issue of 29 April as a non-resignation. 
ticket issued to her as an MP's wife for economy-class tickets for her and her sons. Bruce Scott (September 1997) faced calls to resign over travel rorts (and was almost certainly not promoted because of the issue); Peter Reith (October 2000) over the use of his telecard by his son; Ian MacFarlane and Peter Costello (August 2003) over a claim that they tried to defraud the Tax Office of GST liabilities for a Liberal Party dinner; Helen Coonan (December 2002) for using ministerial letterheads in personal correspondence with an insurance company; Wilson Tuckey for pressurising South Australia's Police Minister to quash a fine incurred by his son; John Anderson (September 2004) over allegations (that he was cleared of) that he tried to bribe an independent MP to give up his seat, and again (June 2005) over selective handouts to Coalition electorates in his role as Transport and Regional Services Minister. Under Rudd, Joel Fitzgibbon did not resign in March 2009 following details of his association with Chinese businesswoman Helen Liu, though he did go three months later after further revelations about their association and that with Fitzgibbon's brother and the fact defence officials felt they were being pushed to do business with Fitzgibbon's brother. Both Rudd and Wayne Swan are also non-resignations in this category (June 2009) over the OzCar scheme where they were accused of pushing business to specific car dealerships.

We can see with regard to financial scandals that, whilst they are more likely to lead to resignations, in some cases ministers do not go even though these cases seem equally as scandalous as ones in which resignation ensues. Howard introduced his code of conduct following his criticisms of ministers in the previous administration for not declaring interests and holding shares; however, he then faced even greater problems over these issues in his own administration and later felt obliged to relax the guidelines. Sometimes resignations occur over relatively trivial sums of money, largely because ministers have been shown to have given misleading statements, and the issue of honesty rather than the original 'crime' is what leads to resignation. Of course, another issue is how important the minister is to the party and the prime minister. Ministers considered to be good or who are close to the prime minister are less likely to go than those the prime minister might be pleased to see the back of, but we do not consider that aspect of forced exits in this chapter.

The main categories that financial scandals fall into are: first, campaigning irregularities; second, inappropriate use of public money, such as travel rorts; and three, suspicious business activities either personally or in the minister's immediate circle. The first lead to resignations if proven; the second tend to lead to resignations, though are more acceptable if ministers can demonstrate lack of personal knowledge. Whether resignations occur in the third seems to depend upon the seriousness of the claims and whether the minister is shown 
to have been dishonest in his first response to the allegations. In all three areas the attitude of the prime minister and the political circumstances of the time are key determinants in how the case unfolds.

The line between a policy dispute and 'personality clash' is a fine one. In the main, policy disputes are those where policy disagreement of some sort is aired in public. We have coded some cases as policy dispute where disagreements within cabinet have been made public by the opposition or media, even though sometimes these might be of a relatively trivial nature. The normative constitutional convention is clear enough in this case. Disputes within government, even when becoming public through leaks, should not lead to resignation no matter what hostile oppositions or the media make of them. Publicising them is mischief making by opposition or the media. We have coded as personality clashes those cases where personal ambition has led to resignation. So personality clash also includes power battles between members of the cabinet, notably leadership battles.

In Australia, as in the United Kingdom and other countries, few ministers resign over 'performance' despite many calls for them to do so. Those who call for a resignation based on the poor performance of a minister rarely expect the minister actually to resign; rather the call is simply a means of getting criticism of the government into the news. We will not report the myriad cases of nonresignation, but mention here those exits we have so coded. The first is Frank Crean in November 1974. After the 1974 election, Cairns was elected Deputy Leader of the Labor Party and asserted his right to a bigger role in economic policy, eventually claiming the Treasury after Crean had been virtually sidelined over the 1974 budget. We have also included the dismissal of the Whitlam Government by the Governor-General in November 1975. There has been much debate over this controversial action, but we have simply coded it as one case due to 'performance'. We code as performance John Dawkins' resignation as Treasurer in December 1993, following months of speculation after his budget had been savaged, which he described as the worst month in his political career. Geoff Prosser resigned in July 1997, telling Prime Minister Howard that he had become a liability to the Government. As indicated above, he had survived earlier calls to resign over his business affairs but question marks remained.

Two things are notable about these data for Australia in comparison with the similar data collected for the United Kingdom. The first is the relative lack of sex scandals. We have coded one non-resignation as a sex scandal, though in truth it is a minor affair compared, for example, with the fuss made in the United Kingdom and the United States (Garment 1991; King 1986; Markovits and Silverstein 1988; Tiffen 1999); indeed it was not presented in the newspapers at the time as explicitly about sex. We code it thus more to make the point that sex 
scandals do not figure much at the federal level. ${ }^{5}$ In fact, it was a call in February 1975 by the Country MP Ralph Hunt for Jim Cairns to resign unless there were to be a public inquiry into the appointment of Junie Morosi as Principal Private Secretary to Cairns - a post usually held at that time within the Treasury by a public servant. What is interesting about this 'sex scandal' in comparison with British and US ones is that, whilst the sexual nature of their relationship was guessed by elites in Canberra, it was not aired in the press until almost 30 years later. Australian newspapers do not seem inclined to pursue Commonwealth politicians with the zeal of their US and British counterparts - unless it is that Australian politicians are less inclined to become involved in such tawdry matters.

The second aspect of the Australian data that is particularly noticeable in relation to the United Kingdom is the necessary addition of a new category of resignation issue. In Figure 6.5 there are five entries where there has been a call for a minister to resign over their policy (and another 42 recorded in the full set). None has done so, which is as significant as the coding itself. Ministers in Australia are much more closely aligned with specific policies than in the United Kingdom. Any such calls for resignation in the United Kingdom would be directed more at the Prime Minister for failures in government policy or possibly at the Chancellor of the Exchequer (Treasurer), or directed at more general performance issues. Specific calls for ministers to resign due to their policies - not the failure of those policies as such but their nature - are, however, common in Australia.

\section{Conclusions}

This chapter is largely descriptive, presenting some general data on ministerial resignations and non-resignations in Australia over a 60-year period. Like all such descriptive studies using data in this manner there are many judgment calls to be made over how to precisely code the events. Sometimes the point of the coding and discussion is to bring out the nature of the event and how unusual it is, such as the case of Cairns. We note that rarely do ministers resign due to 'performance', though arguably prime ministers can sometimes be thought to do so; however, such cases also involve power struggles.

There are a number of features worth noting in our findings. First, the number of resignation issues has increased dramatically over the period. (There was a falling off during the Rudd years, though it is too early to say if this is a trend.) Whilst there has been a slight increase in the number of ministers over that time,

5 They have featured at the State level in the past decade or more. 
this increase cannot explain the dramatic rise. There are a number of factors that might. Whilst the standard constitutional issues - calls for resignation over personal and departmental errors, over the general performance of the minister, over policy disagreements - have been around from the start, calls for resignation (in our data set) over financial irregularities started only in the mid1970s, over personality clashes from the late 1960s (probably due to Menzies being in control for so long) and, whilst we do have one call for a minister to resign over his policies from as far back as 1959, that case is Harold Holt as Treasurer over economic policy. Calls for resignation of ministers due to their policies (we note again this is not policy failure as such, simply criticism of the policy the minister has adopted) started in the late 1960s (with three cases) and then took off dramatically from Whitlam's government in the 1970s. No minister has ever resigned after such a call.

We suggest that the increasing number of resignation issues over time is due to increased media attention, and also to Australian oppositions becoming much more ruthless as they view a potential resignation as a political prize to be pursued. Certainly the call to resign over policy has increased dramatically and is relatively unusual in world terms. With the exception of calls in the United Kingdom for the Chancellor of the Exchequer (the Treasurer, in Australia) to resign during economic crises, such calls are only made on the Prime Minister. Similarly, such calls are rare in Ireland, Germany, Belgium, Canada and other countries for which such dedicated data have been collected (Dowding and Dumont 2009a).

We have discussed the proximate causes of resignation in terms of the reasons for the call for resignation. But we note that the attitude and political judgment of the prime minister are vital. Using Australian data, McAllister (2003) reports that resignations are correlated with falls in government popularity, and, if causal, this ought to make prime ministers reluctant to fire ministers. Dewan and Dowding (2005), however, using British data, argue that it is the resignation issue that is bad for a government's popularity - that resignations in fact provide a corrective effect, increasing government popularity relative to what it would have been. They recognise, however, that prime ministers cannot always sack and the 'political scalp' aspect usually leads prime ministers to defend ministers unless it is clear that the public disapproves. We also note that dishonesty about an issue is often more important than the nature of the issue itself when it comes to whether a minister resigns.

In this chapter we have mapped the outlines of forced exits in the Australian Commonwealth Government in the postwar period. More detailed analysis of our data is required before we can supply a more thorough analysis of the 
cause of forced exits, but this overview provides a start in examining the changing nature of ministerial resignations and public perceptions about those resignations and thus the true nature of sacrificial ministerial accountability.

\section{Acknowledgements}

We thank Anne Gelling, Richard Mulgan, John Nethercote, Rodney Tiffen and John Wanna for their comments. The research reported here was made possible by the Australian Research Council Discovery Grant DP09851986.

\section{Bibliography}

Berlinski, S., T. Dewan and K. Dowding. 2007. 'The Length of Ministerial Tenure in the UK, 1945-1997'. British Journal of Political Science 37(2): 245-62.

Berlinski, S., T. Dewan and K. Dowding. 2010. 'Performance Evaluation of British Ministers'. Journal of Politics 72(1): 1-13.

Berlinski, S., T. Dewan and K. Dowding. 2012. Accounting for Ministers: Scandal and Survival in British Government 1945-2007. Cambridge: Cambridge University Press.

Dewan, T. and K. Dowding. 2005. 'The Corrective Effect of Ministerial Resignations on Government Popularity'. American Journal of Political Science 49(1): 46-56.

Dewan, T. and D. P. Myatt. 2007. 'Scandal, Protection, and Recovery in Political Cabinets'. American Political Science Review 101(1): 63-78.

Dowding, K. 1995. The Civil Service. London: Routledge.

Dowding, K. and P. Dumont (eds). 2009a. The Selection of Ministers in Europe: Hiring and Firing. London: Routledge.

Dowding, K. and P. Dumont. 2009b. 'Structural and Strategic Factors Affecting the Hiring and Firing of Ministers'. In The Selection of Ministers in Europe: Hiring and Firing, eds K. Dowding and P. Dumont. London: Routledge.

Dowding, K. and W.-T. Kang. 1998. 'Ministerial Resignations 1945-97'. Public Administration 76(3): 411-29. 
Dowding, K. and C. Lewis. 2012. 'Culture, Newspaper Reporting and Changing Perceptions of Ministerial Accountability in Australia'. Australian Journal of Politics and History 58: 236-50.

Dowding, K., A. Hindmoor, R. Iles and P. John. 2010. 'Policy Agendas in Australian Politics: The Governor-General's Speeches, 1945-2008'. Australian Journal of Political Science 45: 533-57.

Fischer, J., A. Kaiser and I. Rohfling. 2006. 'The Push and Pull of Ministerial Resignations in Germany, 1969-2005'. West European Politics 29: 709-35.

Garment, S. 1991. Scandal: The Culture of Mistrust in American Politics. New York: Times Books.

Howard, J. 1996. Guidelines on Ministerial Conduct. Canberra: Australian Government Publishing Service.

Keating, M. 2003. 'In the Wake of "A Certain Maritime Incident": Ministerial Advisers, Departments and Accountability'. Australian Journal of Public Administration 62(3): 92-7.

King, A. 1986. 'Sex, Money and Power'. In Politics in Britain and the United States, eds R. Hodder-Williams and J. Ceaser. Durham, NC: Duke University Press.

McAllister, I. 2003. 'Prime Ministers, Opposition Leaders and Government Popularity in Australia'. Australian Journal of Political Science 38(2): 259-77.

McConnell, A., A. Gauja and L. Botterill 2008. 'Policy Fiascos, Blame Management and AWB Limited: The Howard Government's Escape from the Iraq Wheat Scandal'. Australian Journal of Political Science 43(4): 599-616.

McLeay, E. 1995. The Cabinet and Political Power in New Zealand. Auckland: Auckland University Press.

Markovits, A. and M. Silverstein (eds). 1988. The Politics of Scandal: Power and Process in Liberal Democracies. New York: Holmes and Meier.

Marr, D. and M. Wilkinson. 2003. Dark Victory. Sydney: Allen \& Unwin.

Mulgan, R. 2000. 'Accountability: An Ever Expanding Concept'. Public Administration 58(3): 555-74.

Mulgan, R. 2002. 'On Ministerial Resignations (and the Lack Thereof)'. Australian Journal of Public Administration 61(2): 121-7.

Overington, C. 2007. Kickback: Inside the Australian Wheat Board Scandal. Melbourne: Allen \& Unwin. 
Page, B. 1990. 'Ministerial Resignation and Individual Ministerial Responsibility in Australia 1976-1989'. Journal of Commonwealth and Comparative Politics 28(2): 141-61.

Thompson, E. and G. Tillotsen. 1999. 'Caught in the Act: The Smoking Gun View of Ministerial Responsibility'. Australian Journal of Public Administration 58(1): 48-57.

Tiffen, R. 1999. Scandals, Media, Politics, and Corruption in Contemporary Australia. Sydney: UNSW Press.

Volcker, P. 2005. 'Manipulation of the Oil-for-Food Programme by the Iraqi Regime'. Washington, DC: United Nations. <http://www.iic-offp.org/ documents/IIC\%20Final\%20Report\%20270ct2005.pdf $>$, viewed August 2010 .

Weller, P. 2002. Don't Tell the Prime Minister. Melbourne: Scribe.

Woodhouse, D. 1994. Ministers and Parliament: Accountability in Theory and Practice. Oxford: Oxford University Press. 


\section{Appendix 6.1}

All ministers from the beginning of Menzies' fourth ministry (1949) were listed. In this chapter we make no distinction between inner and outer ministries. We then carried out a systematic search for all 'resignation issues' in various newspaper databases. A 'resignation issue' is defined as any issue over which there was a call for a minister to resign by a parliamentarian, a responsible agent such as a professional organisation, lobby group or trade union, or in an editorial or column in one of our newspapers. Cases where ministers resigned prior to any public discussion also constitute resignation issues. The information was downloaded and a short descriptive paragraph of each event written up. From those descriptions all cases were coded into 10 categories: Personal Error; Departmental Error; Sexual Scandal; Financial Scandal; Policy Disagreement; Personality Clash; Performance; Other Controversy; Ill Health; Criticism of Minister's Policy. Whilst some cases had secondary as well as primary causes coded, we utilise only the primary categories in this chapter. These categories were based on those used for a similar study in the United Kingdom (Dowding and Kang 1998) though, as discussed in the text, it was necessary to create additional categories.

In some cases an issue emerges, goes away and then returns. In such cases, if there is a gap of a week or more in reporting, we code it first as a non-resignation and then as a resignation. Similarly, if two issues are bundled together, we code the earlier as a non-resignation and the second that leads to the exit as resignation.

For consistency over the period, we concentrated upon information from the Sydney Morning Herald (SMH), though for parts of the period further information (not cases) was also taken from other newspapers - notably, The Age and The Australian. The Factiva database (<Factiva.com $>$ ) was utilised to access articles from September 1986 to December 2007. The $S M H$ was available from 1 September 1986, The Age from 19 January 1991 and The Australian with articles available from 8 July 1986. The $S M H$ archives site (<http://archives. smh.com.au/>) was utilised for the 1955-95 period. For articles prior to 1955, information was obtained via microfiche files from the National Library of Australia's Canberra facilities. Relevant information in relation to ministerial resignations from Internet databases (1955-2007) was obtained by typing the minister's name in Factiva followed by the word 'resign*' (for example, 'Keating resign $^{* \prime}$ ). Information for the period 1949-54 was acquired though a microfiche search. All entries for individual ministers were noted from the $S M H$ index books from the National Library of Australia, and by manually viewing the first three pages of all SMH newspapers on microfiche. All material was collected by one researcher who also initially coded the data. The coding was subsequently checked and discussed with another researcher. 
Other sources of information used to support data search and check information were: Department of Parliamentary Library, That's It-I'm Leaving and Other Kirribilli Tales, Ministerial Resignations and Dismissals 1901-1991, the Parliament of the Commonwealth of Australia (<http://www.aph.gov.au/index. htm $>$ ); and Wikipedia and Google searches of different Australian federal governments and ministers. Further background information on cases was also collected from various biographies and secondary sources. 